\title{
The design, implementation and evaluation of mass conferencing
}

\author{
Karl Donert, Sean Brady and Jean Clarkson \\ Liverpool Hope University College
}

There have been attempts to classify and analyse the approaches and techniques of using videoconferencing for teaching and learning. Most classifications include the use of videoconferencing techniques to support lecture-style delivery to large audiences, or what might be referred to as 'mass conferencing'. This is often dismissed by sceptics as another gimmick: the real thing is better, or it may be viewed as simply just another didactic approach with little to commend it either in the form of communication or in pedagogical terms. However, the key element in its use is the context within which the mass conferencing is being applied. Whatever videoconferencing approaches are employed, it is our view that their successful implementation implies both a clearly defined structure and an operational template. Thus, this paper underlines some of the processes which we have used in mass conferencing. We then evaluate the outcomes, and identify. some themes to be incorporated in successful mass conferencing, including the key factors involved in successful delivery, namely in the preparation, activity, and evaluation stages. In operational terms, the introduction of an external element, beyond the control of course tutors, has highlighted many organizational, pedagogical and technical questions, some of which we address.

\section{Introduction}

The development of the PC has opened up many new perspectives in the use of technology for distance learning. Broadband, high-speed telecommunications now make it possible to access, transmit and receive sound, still images, video and other data. This application is normally referred to as videoconferencing (Woodruff and Mosby, 1996). It provides the capability to connect two or more parties separated by distance by means of audio, video and data and allows opportunities for real-time interaction. It is often used by groups of people who gather in a specific setting to communicate with other groups of people who are unable physically to be there. However, the term videoconferencing can be applied to a wide range of situations, such as individual-to-individual discussion and video-lecturing. Lopez and Woodruff (1996) identify four videoconferencing formats: the interview, the virtual meeting, the virtual field trip and the lecture. They state that the least productive of these is normally the lecture which, they suggest, does not promote dialogue or interaction: a lecture is as a one-way process where intellectual resources are transmitted, and as a learning environment does not usually provide opportunities for students to interact with 
tutors or between themselves. They are unlikely to establish any form of dialogue or to use their own thought processes (King and Honeybone, 1997). Whilst cost-effective in traditional terms, the lecture forum can be a shallow and relatively ineffective learning experience.

This paper describes, examines and evaluates the outcomes associated with the use of videoconferencing to large audiences. This is referred to as mass conferencing. The audience consists of receptors (students), facilitators (tutors) and technicians at one end of the conference link, and a small number of individuals, normally deliverers (lecturers) and technical support, at the other. It then illustrates that action research has been used to develop a template or framework for the efficient delivery of such activities.

\section{The role of the mass conference}

Liverpool Hope University College is an ecumenical, Church foundation, higher-education establishment with approximately 4,500 students, where a number of experiments using ISDN communications technology have been carried out since early 1995 . At first, simple, one-to-one and one-to-few conferences were used to demonstrate the technology. Then a wide variety of different videoconferencing options were tried. These included conferences between individuals, small audience conferences (Donert, 1997), and larger group conferences with up to 25 people involved, in some cases with applications being shared (Thornton, 1997a; Thornton 1997b).

It was decided that the mass conference should be developed as part of an existing teaching scheme. The implementation of any videoconference requires considerable organization and planning (Dimple, 1995). A mass-conferencing event, however, poses a range of additional issues which include how to make it effective, pedagogically sound, and entirely relevant to the course in question. A number of important aims were set as part of the mass conference: firstly, to enable a face-to-face component, with an expert in the field of teacher education; secondly, to try to maximize the degree of interactivity between all those involved, and specifically to enable interaction between receptor (the students) and deliverer (the lecturer). The final aim was to explain the delivery mechanism to the students, and to involve them in the process in order to maximize the student experience. It was hoped therefore to ensure that the mass conference would generate active participation and limit any perceived impact the technology might have.

\section{The pedagogical challenge}

There is a considerable wealth of research literature about learning and teaching with videoconferencing. Many researchers, for example Galbreath (1995) and Reed and Woodruff (1995), have looked specifically at the impacts of videoconferencing technology. Threlkeld and Brzoska (1994) and Rettinger (1996) explored the learning environments which they have created using videoconferencing technology. There have been several attempts (Bray et al, 1995; Richards, 1996; Gilcher, 1997; Kronlund, 1997) to classify the pedagogical approaches used with videoconferencing. As a result, considerable guidance (Burge and Roberts, 1993; Schnurr and Smith, 1995) and advice (Coventry, 1996) have been made available for those who want to use it effectively. However, Gale (1992) and McPhee (1997) comment that there have been relatively few evaluations of the effectiveness 


\begin{tabular}{|c|c|c|}
\hline Course development & $\begin{array}{l}\text { Tutor } \\
\text { activities }\end{array}$ & $\begin{array}{l}\text { Student } \\
\text { activities }\end{array}$ \\
\hline Préparatory phase & $\begin{array}{c}\text { Identify aims, } \\
\text { plan course, } \\
\text { organize mass conference, } \\
\text { produce materials. }\end{array}$ & $\begin{array}{l}\text { Read literature, } \\
\text { consider ideas, } \\
\text { initial discussion. }\end{array}$ \\
\hline Activity phase & $\begin{array}{l}\text { Survey preparation, } \\
\text { deliver seminar, } \\
\text { organization of mass } \\
\text { conference. }\end{array}$ & $\begin{array}{l}\text { Literature search, } \\
\text { discussion, } \\
\text { continued reading. }\end{array}$ \\
\hline $\begin{array}{l}\text { Central component: } \\
\text { the mass conference }\end{array}$ & $\begin{array}{l}\text { Deliver conference, } \\
\text { introduction (the technology } \\
\text { the pedagogy, the theme of } \\
\text { the conference), evaluate mass } \\
\text { conference. }\end{array}$ & $\begin{array}{l}\text { Participation, } \\
\text { critical thought, } \\
\text { reflection. }\end{array}$ \\
\hline Evaluative phase & $\begin{array}{l}\text { Deliver evaluative seminar, } \\
\text { full review of course. }\end{array}$ & $\begin{array}{c}\text { Reflection, } \\
\text { consider assignment, } \\
\text { group discussion, } \\
\text { further reading, } \\
\text { complete assignment. }\end{array}$ \\
\hline Follow-up phase & $\begin{array}{l}\text { Analysis of evaluation, } \\
\text { mark coursework, } \\
\text { provide feedback } \\
\text { redesign course. }\end{array}$ & $\begin{array}{l}\text { Receive feedback } \\
\text { reflect on } \\
\text { performance. }\end{array}$ \\
\hline
\end{tabular}

Figure 1: Course development phases in mass conferencing

of the technology as a teaching and learning tool. Abbot et al (1993) describe student videoconferencing experiences. Their students felt that videoconferencing lent itself best to lectures and least to free-flowing discussions. The difficulty of generating two-way interaction was seen to be caused by the technology. As for outcomes, Meisalo (1996) has shown that there was no significant difference in student academic performance when using videoconferencing: the students involved in videoconferencing performed as well as those who attended normal lectures. The students commented, however, that they disliked video lectures because it was very difficult to achieve class interaction.

Thus the challenge was to demonstrate that mass conferencing could incorporate the benefits of face-to-face interaction. We also wanted to identify whether the use of the technology would have a real impact on the learning effectiveness and the attitudes of the students concerned. 
At an early stage it was recognized that the learning environment created during the course would be central to the level of student involvement in the mass conference. As a result, planning of the whole course was co-ordinated around the mass conference. Specifically, there were five course-development phases: a preparatory phase, an activity phase, the mass conference event, an evaluative phase and a follow-up phase (see Figure 1).

\section{The pedagogical framework employed}

Three pedagogical strategies, or modes of interaction, were incorporated in the mass conference: collaboration mode, lecture mode and dialogue mode (see Figure 2). Lecture mode is a 'one-to-many' interaction, where there are distinct and unequal roles played by those delivering and those participating. There is typically one lecturer, who is active in his/her approach, and many students, who are normally relatively passive. Collaboration mode is a 'many-to-many' interaction. Each participant is fully, though not equally, involved. There is commonly a facilitator who enables and leads the interaction. This mode was used during the mass conference to create a dialogue between the audience and the speaker. It was achieved by using a 'question-time' format, where students had previously discussed the literature in seminars and produced a question for the expert, which was then allowed to develop into a further interactive question after the response. Enquiry mode involves students in deeper thought processes, developing a critical awareness of the issues which were discussed. If the learner questions knowledge, there needs to be social interaction or dialogue which is reciprocal in nature. The successful use of learning technology should provide such a dialogue (Good, 1995). It was therefore important to involve the students in the process, rather than allowing them to be simply passive receptors of knowledge and ideas. This was attempted by varying the delivery mechanisms employed and explaining the technology and the procedures involved.

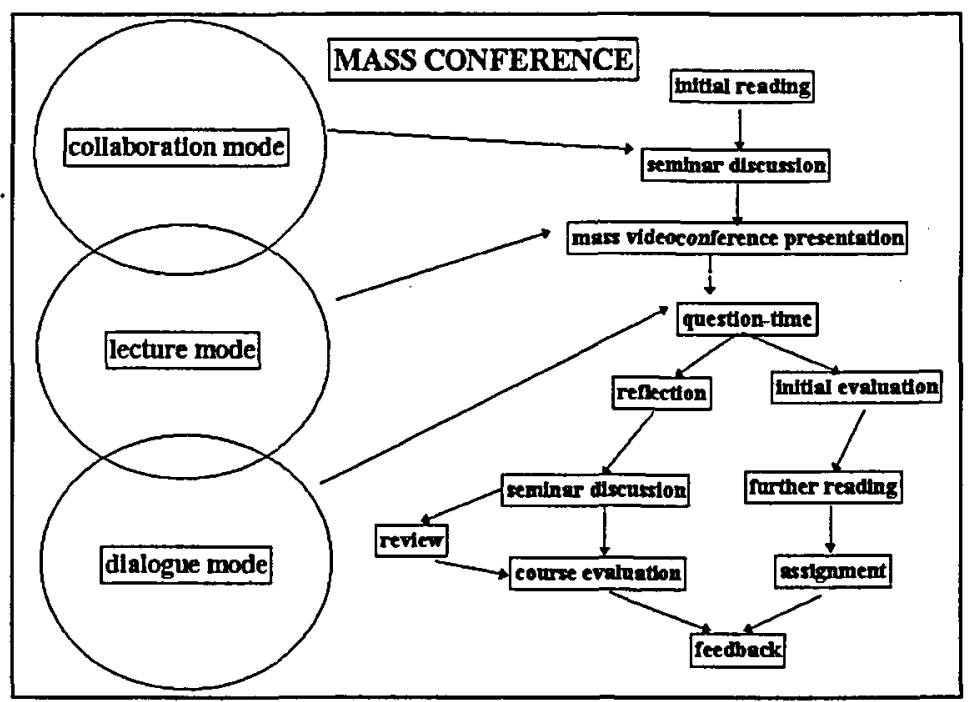

Figure 2: Mass conferencing pedagogical strategies

It has been argued (Edigo 1988, O'Malley et al 1994) that two-way videoconferencing cannot serve as a direct replacement for face-to-face contacts. However public figures are not normally available because of limitations of time, cost and distance. 
Videoconferencing can make them accessible. Other research (Schiller and Mitchell, 1992; Bruce, 1994) indicates that videoconferencing filters and distorts many of the (often unconscious) signals used in face-to-face situations. These signals include lip reading, body movement, gaze and eye contact. Such signals are used to regulate, maintain and progress verbal interactions. The mass conference sought to maximize the effectiveness of the available technology in order to minimize its impacts on the delivery.

\section{Varying delivery styles}

The mass conference allowed those involved in the course to provide a study unit which involved many different activities. These included background reading of recently published works of the 'distant' lecturer, a seminar discussion which led to the generation, by each seminar group, of questions for the lecturer, a review of recent literature, the mass conference involving 'lecture-style' delivery then 'question-time'. The unit was concluded with another seminar discussion, reflection and evaluation. Thus the mass conference was fully integrated into the course. The whole event was spiced up with a 'celebrity' attraction, Professor Ted Wragg of Exeter University. This resulted in a very large audience with almost all the students attending on the day.

\section{Research method}

Evaluative surveys of the activity phase and the mass conference itself were carried out. These included a quantitative survey of all participants immediately following the mass conference (sample size: 174). This was followed by a number of in-depth qualitative interviews during the reflective phase (sample size: 6) three weeks after the mass conference. At the completion of the course, an analysis of the outcomes, including the assignments submitted by the students, standard course evaluations were undertaken, and informal feedback from tutors sought.

\section{Research findings}

The quantitative survey investigated four main areas: the perceived impact of the technology, the effectiveness of 'lecture-mode', the impact of 'question time' (collaborative mode), and the whole experience including the discussion and literature (enquiry mode) (see Figure 3).

Only 2 per cent of the audience (four students) had ever experienced videoconferencing in any form. Therefore, unlocking the mystique of the technology just before the conference, in lay terms, is likely to have helped the audience understand some of the potential technical issues such as sound feedback and picture frame delays and so too have minimized the impact of technology on the audience. Taylor (1991) has suggested that visual quality is important, especially for eye contact, and a sense of social presence. Sound quality might have posed problems, for example feedback and low volume levels were difficulties identified during the trial link, so a telephone was used rather than a microphone. The results showed that the technology did not appear to have an impact on the effectiveness of the mass conference. A few students (6 per cent) did, however, report severe sound problems, perhaps associated with their location in the lecture hall.

Gibbs et al (1996) suggest that crowded lecture theatres are not effective environments for 


\begin{tabular}{|c|c|c|c|c|c|}
\hline The Talk & $\begin{array}{c}\text { strongly } \\
\text { disagree (\%) }\end{array}$ & $\begin{array}{c}\text { disagree } \\
(\%)\end{array}$ & $\begin{array}{c}\text { agree } \\
(\%)\end{array}$ & $\begin{array}{c}\text { strongly } \\
\text { agree (\%) }\end{array}$ & $\begin{array}{l}\text { mean } \\
\text { score }\end{array}$ \\
\hline Concentration level maintained & 1 & 11 & 57 & 30 & 1.04 \\
\hline Low levels of involvement & 12 & 33 & 40 & 16 & 0.14 \\
\hline An active approach & 3 & 25 & 58 & 13 & 0.52 \\
\hline Question Time & $\begin{array}{c}\text { strongly } \\
\text { disagree (\%) }\end{array}$ & $\begin{array}{c}\text { disagree } \\
(\%)\end{array}$ & $\begin{array}{l}\text { agree } \\
(\%)\end{array}$ & $\begin{array}{c}\text { strongly } \\
\text { agree (\%) }\end{array}$ & $\begin{array}{l}\text { mean } \\
\text { score }\end{array}$ \\
\hline Not personally involved & 7 & 32 & $4 !$ & 20 & 0.35 \\
\hline Questions thought-provoking & 0 & 6 & 68 & 25 & 1.13 \\
\hline The Technology & $\begin{array}{c}\text { strongly } \\
\text { disagree (\%) }\end{array}$ & $\begin{array}{l}\text { disagree } \\
(\%)\end{array}$ & $\begin{array}{l}\text { agree } \\
(\%)\end{array}$ & $\begin{array}{c}\text { strongly } \\
\text { agree (\%) }\end{array}$ & $\begin{array}{l}\text { mean } \\
\text { score }\end{array}$ \\
\hline Videoconferencing effective & 0 & 2 & 67 & 31 & 1.27 \\
\hline Made session awkward & 20 & 68 & 9 & 3 & -0.94 \\
\hline Sound/vision put me off & 22 & 64 & 11 & 3 & -0.91 \\
\hline Focused on the technology & 14 & 71 & 12 & 2 & -0.82 \\
\hline The Whole Experience & $\begin{array}{c}\text { strongly } \\
\text { disagree (\%) }\end{array}$ & $\begin{array}{c}\text { disagree } \\
(\%)\end{array}$ & $\begin{array}{l}\text { agree } \\
(\%)\end{array}$ & $\begin{array}{c}\text { strongly } \\
\text { agree (\%) }\end{array}$ & $\begin{array}{l}\text { mean } \\
\text { score }\end{array}$ \\
\hline Plan to follow up with reading & 2 & 28 & 64 & 6 & 0.45 \\
\hline Helped clarify issues & 1 & 13 & 76 & 10 & 0.82 \\
\hline Plan to follow up with assignment & 22 & 43 & 29 & 6 & -0.46 \\
\hline Sceptical of the value & 17 & 70 & 12 & 1 & -0.88 \\
\hline \multicolumn{6}{|c|}{$\begin{array}{l}\text { NB: Strong views were scored as }+2 \text { for strong agreement and }-2 \text { for strong disagreement }+1 \text { and }-1 \\
\text { values were given for agreement and disagreement respectively. Mean scores were calculated from } \\
\text { these scores. The larger the mean score above } 0 \text {, the greater the agreement with the statement. Scores } \\
\text { below } 0 \text { were in disagreement with it }\end{array}$} \\
\hline
\end{tabular}

Figure 3: Evaluating the mass conference

knowledge retention and critical thinking. Mean attention spans are likely to be as low as 20 minutes (Hartley, 1997). However, the lecture part of the mass conference was very well reviewed. Most of the audience ( 87 per cent) felt that they had maintained their level of concentration throughout, and that they had taken an active approach to this part of the mass conference ( 71 per cent). It was clear, however, that those who had experienced technical problems did not have a positive experience. This was to be expected, but it is worth noting that 56 per cent of the students felt relatively low levels of involvement in the lecture. This may have been a function of their location in the audience, but could also have been associated with the length of the formal presentation, which lasted about 35 minutes.

Question time allowed a member of each seminar group to ask an expert a question on the lecture topic. Seminar groups had discussed and prepared their question in advance, and had selected someone to ask it. It was hoped that this would provide the students with a 
feeling of 'ownership' of the question and thus greater involvement in this part of the mass conference. It was thus surprising that most of the students (61 per cent) did not feel personally involved in question time, despite the fact that 93 per cent of them found the questions thought-provoking.

Evaluating the whole experience provided an opportunity to look at the effectiveness of the mass conference in respect of the whole course. Most of the students (70 per cent) planned to follow up the mass conference with reading; 86 per cent felt that the course helped clarify the issues; and 35 per cent planned to follow it with an assignment. A small proportion (13 per cent) were, however, sceptical of the value of the experience; almost all of these students had experienced some technical difficulties.

The other surveys backed up the quantitative findings. Students mentioned that there were technical problems in the lecture theatre. As part of their normal course evaluation, the course was well reviewed by most students as being relevant and generating considerable thought. The assignment connected to the mass conference was selected only by a small proportion of the students (17 per cent), but the student outcomes were relatively high compared with the other options chosen.

\section{Conclusion}

The technology allows the constraints of time, cost and distance to be reduced in bringing the expert face to face with individual students and a large audience. Mass conferencing can be an effective delivery mechanism, provided that technical issues can be resolved. The transition from video-lecturing to mass conferencing also requires an effective pedagogical approach. Effective mass conferencing is therefore a function of the partnership between those involved and the pedagogical strategies which are adopted to maintain the engagement of the audience. The face on the screen can more than equate with the local lecturer, especially when that person is a well-known expert. Perhaps this implies the development of the Virtual Campus, with courses that incorporate real-time input from international experts?

It has been possible to devise a template for successful mass conferencing which involves three key areas, organization, technology and pedagogy. But it is not possible to generalize the planning of mass conferencing without due consideration of the context in which it is to be carried out; the educational scenario, the group size, the role of the tutors and the lecturer, the number of sites involved, and the motivation of the participants. Considering that pedagogical research has lagged far behind technological advances, it might be argued that videoconferencing is still best suited to relatively low-interaction lecturing to large groups. This is certainly the case if the relative costs of establishing the link are considered and compared with the great benefits which can result, even if using technology such as this is a risky business.

\section{References}

Abbot, L., Dallat, J., Livingston, R. and Robinson, A. (1993), Teaching and Learning in the University of Ulster: Videoconferencing and Distance Learning, London: Whittaker.

Bray, T., Dean, J., Dershimer, C., DiGiuseppe, J., Laxton, C., Leifer, D. and Saunders, E. 
(1995), 'Distance learning: planning considerations and options', http://dmi.oit.itd. umich. edu/reports/DistanceLearn/

Bruce, V. (1994), 'The role of the face in face-to-face communication: implications for videophone design' in Emmott, S. and Travis, D. (eds), Proceedings of the International Symposium on POTS to PANS: User Issues in the Multimedia Revolution from Plain Old Telephony Services to Pictures and Network Services, Suffolk: British Telecom.

Burge, E. J. and Roberts, J. M. (1993), Classrooms with a Difference: A Practical Guide to the Use of Conferencing Technologies, Ontario, Canada: The Ontario Institute for Studies in Education.

Coventry, L. (1996), 'Videoconferencing in higher education', http://info.mcc.ac.uk/ CGU/ SIMA/video3/contents.htm

Dimple, G. (1995), 'Advances towards inter-provincial classroom', http://www.cc.ubc.cal ccandc/jul-aug95/video.html

Donert, K. (1997), 'Videoconferencing with small audiences', http://www.livhope. ac.uk/ livhope/ebs/ebswww/WWW/tele.htm

Edigo, C. (1988), 'Videoconferencing as a technology to support group work: a review. of its failure', Proceedings of $C S C W ' 88,13-24$.

Galbreath, J. (1995), 'Compressed digital videoconferencing', Educational Technology, 35 (1), 31-8.

Gale, S. (1992), 'Desktop videoconferencing: technical advances and evaluation issues', Computer Communications, 15 (8), 517-25.

Gibbs, G., Lucas, I. and Simonite, V. (1996), 'Class size and student performance 1984-1994', Studies in Higher Education, 27 (3), 261-74.

Gilcher, K. (1997), 'Three models of distance education', http://www.umuc.edu/ide/ modldata.html\#desc-a

Good, D. (1995), Cognitive Technology: The Human Interface, Amsterdam: North Holland.

Hartley, J. (1997), 'The costs of crowded classrooms', The New Academic, 6 (2), 17-18.

King, A. and Honeybone, A. (1997), 'Needs before means: the dialectic of learning and technology', ALT-J, 4 (2), 4-16.

Kronlund, T. (1997), 'New learning perspectives for remote classrooms using videoconferencing', http://www.nks.no/fjernund/worddoc/17kronlu.html

Lopez, A. and Woodruff, M. (1996), 'Vistium, training for videoconferencing', http:/l www.kn.pacbell.com/wired/vidconf/vistium.html.

McPhee, A. (1997), 'Current research in videoconferencing and its potential applications in teacher education' in McDonald, S. and McPhee, A., Computer-Mediated Communication and Videoconferencing in Teacher Education: An Example from Scotland, University of Helsinki: Olé Publications. 
Meisalo, V. (ed) (1996), The Integration of Remote Classrooms: A Distance Education Project Using Videoconferencing, Research Report 160, University of Helsinki, Department of Teacher Education.

O’Malley, C., Langton, S. and Bruce, V. (1994), 'The effects of delay on video-mediated communication', paper presented to the London Conference of the British Psychological Society, 19-20 December 1994, Institute of Education, London.

Reed, J. and Woodruff, M. (1995), 'Using compressed video for distance learning', http:/l www.kn.pacbell.com/wired/vidconf/Using.html

Rettinger, L.A. (1996), 'Desktop videoconferencing: technology and use for remote seminar delivery', http://www2.ncsu.edu/eos/service/ece/project/succeed/info/larettin/thesis/toc.html

Richards, G. (1996), 'SEEDS: a critical framework for implementing educational technologies', http://malun1.mala.bc.ca/seeds/critical/index.html

Schiller, J. and Mitchell, J. (1992), 'Interacting at a distance: staff and student perceptions of teaching and learning via videoconferencing', AARE/NZARE Joint Conference Educational Research, http://www.swin.edu.au/aare/conf92

Schnurr, C. and Smith, C. (1995), 'Videoconferencing in education: meeting teachers' and learners' support and training needs', http://www.man.ac.uk/MVC/SIMA/video4/ title.html

Taylor, J. C. (1991), 'Distance education and technology: a conceptual framework', paper given at the National Distance Education Conference on Education and Technology, cited in Coventry, L., 'Videoconferencing in higher education', http://www.man.ac.uk/MVC// SIMA

Thornton, P. (1997a), 'Interactive educational environmental questionnaire case study', http://www.ex.ac.uk/telematics/JISC/final_report/envques.htm

Thornton, P. (1997b), 'EuroTurtle World-Wide Web Site case study', http://Www.ex.ac.uk/ telematics/JISC/final_report/euroturt.htm

Threlkeld, R. and Brzoska, K. (1994), 'Research in distance education' in Willis, B. (ed), Distance Education: Strategies and Tools, Englewood Cliffs NJ: Educational Technology Publications.

Woodruff, M. and Mosby, J. (1996), 'A brief description of videoconferencing videoconferencing in the classroom and library', http://www.kn.pacbell.com/wired/ vidconf/description.html\#what 